\title{
Effects of Metal Oxide Nanoparticles on Toll-Like Receptor mRNAs in Human Monocytes
}

\author{
Vladislav A. Vasilichin ${ }^{1}$, Sergey A. Tsymbal ${ }^{1}$, Anna F. Fakhardo ${ }^{1}{ }^{\mathbb{B}}$, Elizaveta I. Anastasova ${ }^{1}$, \\ Andrey S. Marchenko ${ }^{1}$, Alexander A. Shtil ${ }^{1,2}$, Vladimir V. Vinogradov ${ }^{1, *(D)}$ and \\ Elena I. Koshel 1,*(D) \\ 1 International Institute Solution Chemistry of Advanced Materials and Technologies, ITMO University, \\ 197101 St. Petersburg, Russia; vasilichin@scamt-itmo.ru (V.A.V.); zimbal@scamt-itmo.ru (S.A.T.); \\ fakhardo@scamt-itmo.ru (A.F.F.); anastasova@scamt-itmo.ru (E.I.A.); marchenko@scamt-itmo.ru (A.S.M.); \\ shtil@scamt-itmo.ru (A.A.S.) \\ 2 Blokhin National Medical Research Center of Oncology, 115478 Moscow, Russia \\ * Correspondence: vinogradov@scamt-itmo.ru (V.V.V.); koshel@scamt-itmo.ru (E.I.K.); \\ Tel.: +7-921-890-6773 (V.V.V.); +7-931-579-2993 (E.I.K.)
}

Received: 15 November 2019; Accepted: 5 January 2020; Published: 10 January 2020

check for updates

\begin{abstract}
For the widespread application of nanotechnology in biomedicine, it is necessary to obtain information about their safety. A critical problem is presented by the host immune responses to nanomaterials. It is assumed that the innate immune system plays a crucial role in the interaction of nanomaterials with the host organism. However, there are only fragmented data on the activation of innate immune system factors, such as toll-like receptors (TLRs), by some nanoparticles (NPs). In this study, we investigated TLRs' activation by clinically relevant and promising NPs, such as $\mathrm{Fe}_{3} \mathrm{O}_{4}, \mathrm{TiO}_{2}, \mathrm{ZnO}, \mathrm{CuO}, \mathrm{Ag}_{2} \mathrm{O}$, and $\mathrm{AlOOH}$. Cytotoxicity and effects on innate immunity factors were studied in THP-1(Tohoku Hospital Pediatrics-1) cell culture. NPs caused an increase of TLR-4 and -6 expression, which was comparable with the LPS-induced level. This suggests that the studied NPs can stimulate the innate immune system response inside the host. The data obtained should be taken into account in future research and to create safe-by-design biomedical nanomaterials.
\end{abstract}

Keywords: nanoparticles; toll-like receptors; cytotoxicity

\section{Introduction}

Nanostructured materials are currently being exploited in a range of biomedical applications, including bioimaging, biosensing, diagnosis, and therapy [1-9]. Metal oxide nanoparticles (NPs) have gained considerable attention owing to their unique physical and chemical properties, and have broad applications in nanomedicine [10-13].

In particular, the iron oxide $\mathrm{NPs}, \mathrm{Fe}_{3} \mathrm{O}_{4}$ (magnetite), are MRI contrast agents used for the imaging of cancer, and of cardiovascular and inflammatory diseases [14,15]. In addition, magnetite has been approved by the Food and Drug Administration (FDA) and the European Medicines Agency (EMA) for the treatment of iron deficiency anemia [16]. Titanium dioxide $\left(\mathrm{TiO}_{2}\right) \mathrm{NPs}$ are used for cleaning air and water, and are used in pigments, cosmetics, and skincare products [17]. Zinc oxide $(\mathrm{ZnO}) \mathrm{NPs}$ are among the most commonly used nanomaterials, with a wide range of applications including biomedical imaging, drug and gene delivery, biosensing, and antibacterial and antifungal applications [18]. Copper oxide ( $\mathrm{CuO})$ has a high potential in the development of biosensors [19-21], antifouling coatings [22,23], and biocidal [24-26] and antitumor agents [27-29]. Boehmite (AlOOH) can be used as an adjuvant for vaccines [30,31]. Silver oxide $\left(\mathrm{Ag}_{2} \mathrm{O}\right) \mathrm{NPs}$ have the potential for diagnostic biological probes [32], and antibacterial and anticancer agents [33-35]. 
After uptake into the body, NPs are recognized by the immune system, which can suppress or activate NPs [36-38]. It is supposed that even non-toxic NPs are able to alter a normal defense reaction toward toll-like receptor (TLR) ligands. TLRs are transmembrane proteins that recognize a wide range of "foreign" materials [39,40]. TLRs play a key role in the activation of innate immunity by recognizing specific molecular patterns. Compounds recognized by TLRs are primarily the components of microbial cells. Additionally, recent results provided evidence that TLRs can be activated by metal oxide NPs [41]. In particular, $\mathrm{TiO}_{2}, \mathrm{ZnO}, \mathrm{ZrO}_{2}$, and silver NPs modulated the immune responses via TLRs [42,43].

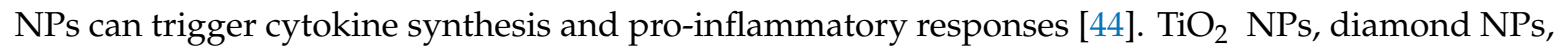
and Pt NPs can activate pro-inflammatory cytokine production, dendritic cell maturation, and naive $\mathrm{T}$ cell activation and proliferation $[45,46]$. ZnO NPs increased the expression of IFN- $\gamma$ (Interferon gamma), TNF- $\alpha$ (Tumor necrosis factor alpha), and IL-12 (Interleukin 12) in primary human immune cells [47]. $\mathrm{TiO}_{2}$ and $\mathrm{SiO}_{2}$ NPs can activate the NLRP3 inflammasome and IL-1 release in human macrophage cell line THP-1, and in lipopolysaccharide (LPS)-primed murine bone marrow-derived macrophages $[48,49]$. Thus, it becomes apparent that the interactions between NPs and immune cells emerge as an essential area of nanomedicine [50,51].

However, systematic research in this area is limited, leaving gaps in our understanding of the NPs' effects on TLRs and the whole immune system. This study is aimed at the analysis of TLRs' expression as induced by NPs. Cytotoxicity and the effects on the innate immunity factors were studied in THP-1 cell culture, expressing TLR-4 and -6. Most studies of the NPs' ability to modulate inflammatory responses have focused on TLR-4-mediated inflammation [42,43,52]. In addition to TLR-4, many studies have revealed the effects of enhancing of TLR-6 expression. [53,54] Therefore, we focused on these two TLRs. We investigated NPs relevant to nanomedicine, that is, $\mathrm{Fe}_{3} \mathrm{O}_{4}, \mathrm{TiO}_{2}$, $\mathrm{ZnO}, \mathrm{CuO}, \mathrm{Ag}_{2} \mathrm{O}$, and $\mathrm{AlOOH}$. NPs increased the expression of TLR-4 and -6 to various extents. The most potent TLR inductors were $\mathrm{AlOOH}$ NPs. $\mathrm{CuO}$ and $\mathrm{TiO}_{2} \mathrm{NPs}$ also stimulated the expression of both TLRs, but to lesser extents. The most unreactive were $\mathrm{Fe}_{3} \mathrm{O}_{4} \mathrm{NPs}$.

\section{Materials and Methods}

\subsection{Chemicals}

Titanium isopropoxide ( $\geq 99 \%$ ), iron (II) chloride tetrahydrate ( $\geq 98.5 \%$ ), iron (III) chloride hexahydrate $(\geq 99 \%)$, copper sulfate pentahydrate, zinc nitrate hexahydrate, aluminum isopropoxide, and MTT powder were obtained from Sigma-Aldrich (St. Louis, MO, USA). Argentum nitrate and ammonia solution (25\%) were purchased from LenReactiv (Saint-Petersburg, Russia). Deionized water was from Elix Essential 3UV, Millipore from Merck (Darmstadt, Hessen, Germany). Dimethyl sulfoxide (DMSO) was from VWR (VWR International, Radnor, PA, USA). The RNA extraction kit and the MMLV-RT kit were purchased from Evrogen (Moscow, Russia).

\subsection{Synthesis of NP Sol}

$\mathrm{Fe}_{3} \mathrm{O}_{4} \mathrm{NPs}: 2.5 \mathrm{~g} \mathrm{FeCl}_{2} \cdot 4 \mathrm{H}_{2} \mathrm{O}$ and $5 \mathrm{~g} \mathrm{FeCl}_{3} \cdot 6 \mathrm{H}_{2} \mathrm{O}$ were dissolved in $100 \mathrm{~mL}$ of deionized water under constant stirring (500 rpm). Then, a $12 \mathrm{~mL}$ portion of aqueous ammonia solution was added dropwise to this solution under constant stirring $(500 \mathrm{rpm})$ at room temperature for $3 \mathrm{~min}$. Using a magnet, the formed magnetite precipitate was collected and washed with deionized water until neutral $\mathrm{pH}$ was attained. The washed black precipitate was mixed with $100 \mathrm{~mL}$ of deionized water and subjected to ultrasonic treatment $(37 \mathrm{kHz}, 110 \mathrm{~W})$ under constant stirring (300 rpm). The duration of the ultrasonic treatment was $120 \mathrm{~min}$.

$\mathrm{TiO}_{2}$ NPs: $3.9 \mathrm{~mL}$ titanium isopropoxide was injected into $50 \mathrm{~mL}$ deionized water, followed by heating to $85{ }^{\circ} \mathrm{C}$ and stirring at $500 \mathrm{rpm}$ for $15 \mathrm{~min}$. The obtained suspensions were treated with ultrasound $(260 \mathrm{~W}, 60 \mathrm{~Hz})$ and simultaneously stirred for $160 \mathrm{~min}(300 \mathrm{rpm})$. The prepared $\mathrm{TiO}_{2} \mathrm{sol}$ was stored in plastic vials at room temperature. 
ZnO NPs: Zinc oxide NPs were synthesized by the precipitation method. Zinc nitrate hexahydrate ( $3.0 \mathrm{~g}$ ) was put into a small beaker and dissolved in $50 \mathrm{~mL}$ of distilled water to obtain $0.2 \mathrm{M}$ concentration. The solution was heated to $91{ }^{\circ} \mathrm{C}$ under constant stirring (450 rpm), and $2 \mathrm{~mL}$ of $1 \mathrm{M} \mathrm{NaOH}$ were added, until a massive amount of white precipitate was obtained. It was centrifuged $(8000 \mathrm{~g}, 10 \mathrm{~min})$ and washed with water and ethanol. The final solution was prepared in water.

$\mathrm{Ag}_{2} \mathrm{O}$ NPs: The same approach was used for the synthesis of argentum oxide NPs. The solution of silver nitrate $(0.1 \mathrm{M})$ was prepared in $50 \mathrm{~mL}$ of distilled $\mathrm{H}_{2} \mathrm{O}$. It was heated to $98{ }^{\circ} \mathrm{C}$ under vigorous stirring, then $1 \mathrm{~mL}$ of $5 \mathrm{M} \mathrm{NaOH}$ was added until a large amount of black precipitate was obtained. After centrifugation and several washings in water and ethanol, $\mathrm{Ag}_{2} \mathrm{O} \mathrm{NPs}$ were dissolved in water and dried in an oven at $60^{\circ} \mathrm{C}$ for $24 \mathrm{~h}$.

CuO NPs: Copper oxide NPs were synthesized as previously described by Phiwdang et al. [55]. Copper sulfate pentahydrate $\left(1.25 \mathrm{~g}\right.$ ) was dissolved in $50 \mathrm{~mL}$ of distilled $\mathrm{H}_{2} \mathrm{O}$, so the final concentration was $0.1 \mathrm{M}$. The solution was heated to $100{ }^{\circ} \mathrm{C}$ under constant stirring ( $\left.450 \mathrm{rpm}\right)$. Then, $2 \mathrm{~mL}$ of $5 \mathrm{M}$ $\mathrm{NaOH}$ were added under vigorous stirring until the solution turned black. The obtained NPs were centrifuged and washed several times in water and ethanol. Dried copper oxide NPs were used for further characterization and concentration determination.

AlOOH NPs: Boehmite NPs were synthesized as previously described [56-58], where $2.2 \mathrm{~g}$ of $\mathrm{Al}\left(\mathrm{C}_{3} \mathrm{H}_{7} \mathrm{O}\right)_{3}$ were added to $50 \mathrm{~mL}$ of deionized water at $90{ }^{\circ} \mathrm{C}$, and a white precipitate was formed immediately. Before ultrasound treatment, the precipitate was kept at $90{ }^{\circ} \mathrm{C}$ under vigorous stirring for $15 \mathrm{~min}$ to complete the production of boehmite NPs and to complete the evaporation of the isopropanol formed during hydrolysis. The final suspension was ultrasonically treated for $2 \mathrm{~h}$, after which a viscous sol was formed. The resulting sol was cooled to room temperature.

\subsection{Characterization Techniques}

The crystal phase and crystallinity of samples were studied by the X-ray diffraction (XRD) method (Rigaku SmartLab 3 diffractometer (Tokyo, Japan) of the engineering center of the Saint Petersburg State Technological Institute (Technical University)) using $\mathrm{Cu}-\mathrm{K} \alpha$ irradiation $(\lambda=1.54 \AA$ A). Samples were scanned along $2 \theta$ in the range of $10-70^{\circ}$ at 0.5 degrees $/ \mathrm{min}$. For XRD analysis, samples were dried at $120^{\circ} \mathrm{C}$ for $4 \mathrm{~h}$. For SEM analysis, the samples were dried in vacuo for $2 \mathrm{~h}$ and examined using a Tescan VEGA 3 scanning electron microscope (Brno, Czech Republic). The particle size and zeta potential in colloidal solutions were measured using a Photocor EPM/Photocor Compact Z (Moscow, Russia). The surface area, pore volume, and pore size distribution were investigated using Quantachrome Nova 1200e (Boynton Beach, FL, USA) by nitrogen adsorption at $77 \mathrm{~K}$, and analyzed using the BET and BJH equations. Prior to analysis, all samples were degassed at $110^{\circ} \mathrm{C}$ for $4 \mathrm{~h}$.

\subsection{MTT Assay}

To evaluate the NPs' cytotoxicity, the human monocytic THP-1 cells were maintained in RPMI 1640 (Biolot, Saint-Petersburg, Russia) supplemented with 10\% fetal bovine serum (Gibco, Australia) and $50 \mu \mathrm{g} / \mathrm{mL}$ gentamycin (Biolot Saint-Petersburg, Russia) at $37^{\circ} \mathrm{C}, 5 \% \mathrm{CO}_{2}$. Cells at a logarithmic phase of growth were plated $\left(5 \times 10^{3} /\right.$ well $)$ into 96-well plates and treated for $72 \mathrm{~h}$ with NPs resuspended directly in the culture medium to reach final concentrations of $0.23-30 \mu \mathrm{g} / \mathrm{mL}$. The volume of added NPs from the stock in water was $<5 \%$ of the total volume of the culture medium in the wells. After the completion of cell exposure, $20 \mu \mathrm{L}$ MTT (3-(4,5-dimethylthiazol-2-yl)-2,5-diphenyltetrazolium bromide; $0.5 \mathrm{mg} / \mathrm{mL}$ ) solution in saline buffer were added to each well for $1.5 \mathrm{~h}$. Then the solution was aspirated, and formazan granules were dissolved in $200 \mu \mathrm{L}$ of dimethyl sulfoxide. Optical density was measured at $570 \mathrm{~nm}$ on a Tecan Infinite 50 spectrophotometer (Mennedorf, Switzerland). Cell viability was calculated as the percentage of optical densities in wells, with each concentration of NPs normalized to the optical density of untreated cells (100\%). 


\subsection{NPs' Influence on TLR Gene Expression}

Cells at the logarithmic phase of growth were plated $\left(10^{6} /\right.$ well) into 6-well plates and treated for $24 \mathrm{~h}$ with NPs resuspended directly in the culture medium at final concentrations (according to the MTT tests) in which cell viability was $>80 \%$ : for $\mathrm{Fe}_{3} \mathrm{O}_{4}$ and $\mathrm{AlOOH}, 30 \mu \mathrm{g} / \mathrm{mL}$; for $\mathrm{TiO}_{2}, 25 \mu \mathrm{g} / \mathrm{mL}$; for $\mathrm{Ag}_{2} \mathrm{O}, 15 \mu \mathrm{g} / \mathrm{mL}$; for $\mathrm{CuO}, 0.5 \mu \mathrm{g} / \mathrm{mL}$; and for $\mathrm{ZnO}, 1 \mu \mathrm{g} / \mathrm{mL}$. As a positive control for TLR signaling activation, we used lipopolysaccharide (LPS) (Sigma, St. Louis, Missouri, USA).

\subsection{RNA Extraction, Reverse Transcription and Quantitative PCR}

An RNA extraction kit ExtractRNA (Evrogen) was used to extract total RNA from THP-1 cells. Concentration and purity of total RNA obtained after the extraction were quantified based on the absorbance at $260 \mathrm{~nm}$ using a Nanophotometer (Implen, Munich, Germany). Reverse transcription was performed using an MMLV-RT kit containing reverse transcriptase (Evrogen, Moscow, Russia) with the addition of hexamer primers to obtain cDNA from the RNA template. Both total RNA extraction and reverse transcription were performed according to the manufacturer's protocols. Quantitative real-time PCR with the fluorescent probe SYBR-Green was used to assess the TLRs' mRNAs in response to NPs or LPS. To normalize the expression data, we used the housekeeping reference gene beta-2-microglobulin. PCR was performed using the qPCRmix-HS SYBR reagent kit (Evrogen Moscow, Russia). Primers were the following: TLR-4 Forward: GCTCTGCCTTCACTACAGGGACT, Reverse: CTGGGACACCACGACAATAACC; TLR-6 Forward: TGGGCTAACATTAGAGCCGC, Reverse: GGCATGAGGATAATGGAGGCA; beta-2-microglobulin Forward: GATGAGTATGCCTGCCGTGT, Reverse: TGCGGCATCTTCAAACCTCC. Primer sequences were selected using NCBI Primer-BLAST and synthesized in Evrogen. Real-time PCR was performed on a CFX Connect ${ }^{\mathrm{TM}}$ Real-Time PCR Detection System (BioRad Laboratories, Hercules, CA, USA). Relative quantification of gene expression was performed using the comparative $\mathrm{Cq}$ method of calculating threshold cycles of genes of interest. Relative gene expression data were normalized to an internal control [59]. The standard deviation was determined based on values from triplicate samples.

\subsection{Statistics}

Each experiment in mammalian cultures was carried out in triplicate. Data are presented as mean \pm SD. Statistical analyses were performed using the Student's $t$-test or Mann-Whitney test (Statistica 6, StatSoft Inc., Tulsa, OK, USA). Statistical significance was considered at $p<0.05$.

\section{Results and Discussion}

\subsection{Characterization of NPs}

First, we obtained $\mathrm{Fe}_{3} \mathrm{O}_{4}, \mathrm{TiO}_{2}, \mathrm{ZnO}, \mathrm{Ag}_{2} \mathrm{O}, \mathrm{CuO}$, and $\mathrm{AlOOH}$ NPs. The XRD analysis (Figure $1 \mathrm{~A}$ ) revealed that each material was highly crystalline. The $\mathrm{XRD}$ patterns were recorded within the fraction angle range of $10^{\circ}$ to $70^{\circ}$. Thus, the XRD pattern of iron oxide showed that the main crystal phase is magnetite (JCPDS file No. 19-0629). Scherrer equation analysis indicated that the magnetite crystallites are of $\sim 10 \mathrm{~nm}$. Silver NPs revealed the diffraction peaks in the XRD pattern matched with $\mathrm{Ag}_{2} \mathrm{O}$ (JCPDS file No. 42-0874), with XRD peaks of $26^{\circ}$ and $32^{\circ} 2 \theta$, which are the indicators of $\mathrm{Ag}_{2} \mathrm{O}$ NPs [60]. The characteristic peaks of copper oxide located at $2 \theta$ were equal to $32.58^{\circ}, 35.47^{\circ}$, and $38.97^{\circ}$ for $\mathrm{CuO}$ (JCPDS file No. 80-1268), while the main phase was tenorite. The XRD of zinc oxide showed broad peaks at values of $31.9^{\circ}, 34.5^{\circ}, 36.3^{\circ}$, and $62.0^{\circ}$, typical for the zinc oxide structure (JCPDS file No. 36-1451). In the case of titanium oxide, the main phase is anatase (JCPDS file No. 21-1272) with the crystallite size of $12 \mathrm{~nm}$. All diffraction peaks in AlOOH samples were indicative of a boehmite (JCPDS file No. 21-1307) crystalline phase with a crystallite size of $6 \mathrm{~nm}$. 

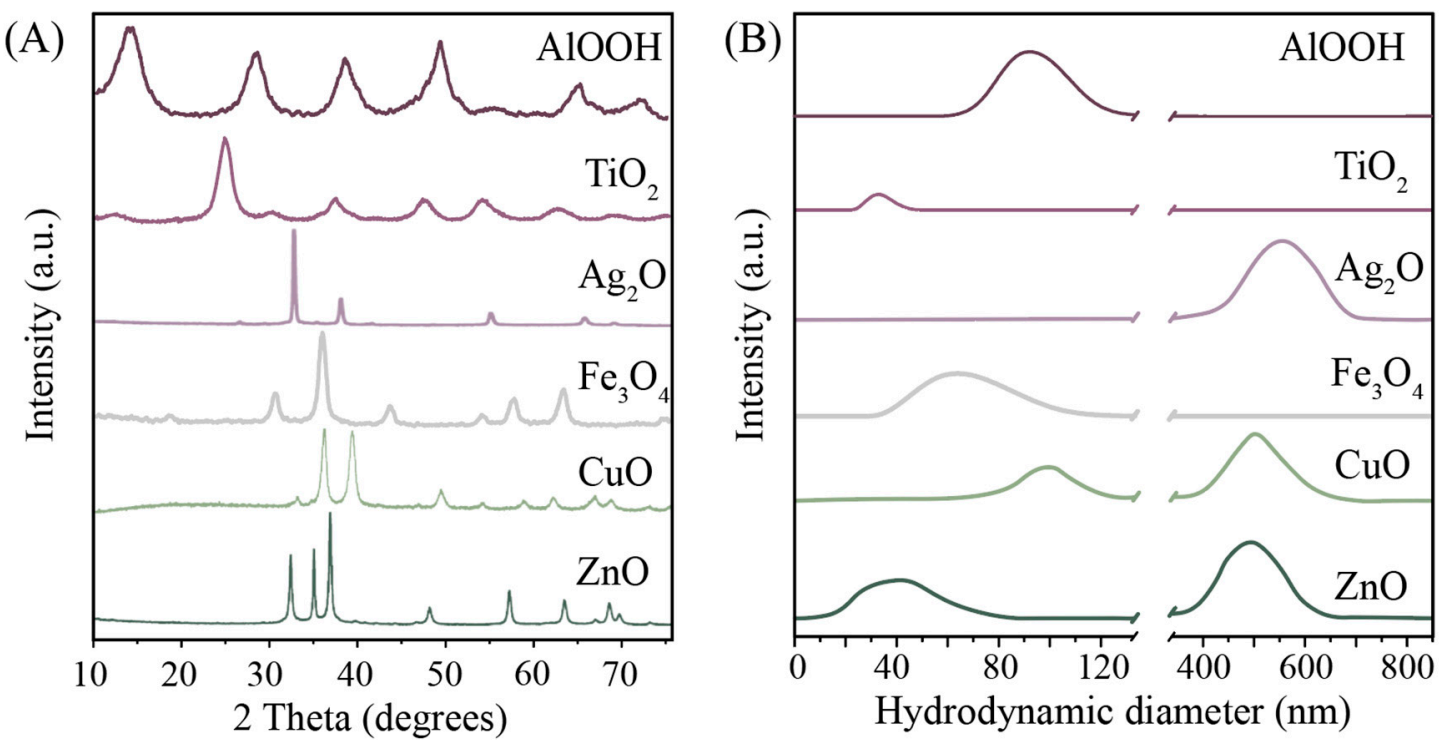

Figure 1. (A) X-ray diffraction (XRD) patterns of dried metal oxides; (B) DLS particle size distribution in the sols.

The described procedures allowed us to obtain the hydrosols of metal NPs with various parameters. Determining the modality of hydrosols by dynamic light scattering (DLS), we found that the hydrosols of zinc and copper were characterized by a multimodal distribution (Figure 1B). This meant that these hydrosols were less stable compared to the sols of iron, titanium, and alumina oxides. In particular, the hydrodynamic diameter of the resulting particles was $40-600 \mathrm{~nm}$. The reduced physical stability of the hydrosols of zinc, copper, and silver oxides can also be explained by the relatively low value of zeta potential (up to $15 \mathrm{mV}$ modulo). Table 1 presents the values of zeta potential for the studied systems. One may see that the charge of the particles of iron, titanium, copper, zinc, and aluminum is positive, whereas silver NPs are negatively charged $(\zeta=-15 \mathrm{mV})$. It is worth noting that the charge does not affect the stability of aqueous solutions.

Table 1. Hydrodynamic size, zeta potential, and surface parameters of nanoparticles (NPs).

\begin{tabular}{ccccc}
\hline \multirow{2}{*}{ Sample } & \multicolumn{2}{c}{ Hydrosol Parameters } & \multicolumn{2}{c}{ Surface Parameters } \\
\cline { 2 - 5 } & Hydrodynamic Diameter, $\mathbf{n m}$ & Zeta Potential, $\mathbf{~ m V}$ & $\mathbf{S}_{\mathbf{B E T}}, \mathbf{\mathbf { ~ } ^ { \mathbf { 2 } } \mathbf { / g }}$ & Pore Size, $\mathbf{n m}$ \\
\hline $\mathrm{TiO}_{2}$ & $40 \pm 7$ & $+7.2 \pm 0.3$ & 167 & 5 \\
\hline $\mathrm{Ag}_{2} \mathrm{O}$ & $510 \pm 70$ & $-16 \pm 0.3$ & 4 & 3.5 \\
\hline $\mathrm{Fe}_{3} \mathrm{O}_{4}$ & $60 \pm 20$ & $+30.0 \pm 1.2$ & 120 & 9 \\
\hline $\mathrm{CuO}$ & $500 \pm 50$ & $+10.8 \pm 0.4$ & 42 & 3.3 \\
\hline $\mathrm{ZnO}$ & $500 \pm 70$ & $+18.0 \pm 0.3$ & 20 & 3 \\
\hline $\mathrm{AlOOH}$ & $90 \pm 10$ & $+42.0 \pm 0.5$ & 170 & 3.5 \\
\hline
\end{tabular}

The structures of NPs were also analyzed using scanning electron microscopy (SEM; Figure 2). The particle size distribution was determined according to SEM. The samples of $\mathrm{CuO}$ were rods, which explained their large size and multimodal particle size distribution according to DLS. Other new NPs had a spherical shape, while their distribution was quite narrow. A comparison of size distributions by SEM for $\mathrm{Ag}_{2} \mathrm{O}$ and $\mathrm{ZnO}$ with DLS particle distribution demonstrated that the measured results are inconsistent. This fact can be related to particle agglomeration into large clusters.

The surface of metal oxides by low-temperature nitrogen physisorption was studied (Table 1 and Figure 3). All newly synthesized materials were mesoporous with a narrow pore size distribution. 
The surface area calculated by BET was the largest for $\mathrm{TiO}_{2}, \mathrm{Fe}_{3} \mathrm{O}_{4}$, and $\mathrm{AlOOH}$ NPs $(167,120$, and $170 \mathrm{~m}^{2} / \mathrm{g}$, respectively), which is consistent with the initial sizes of the obtained particles.
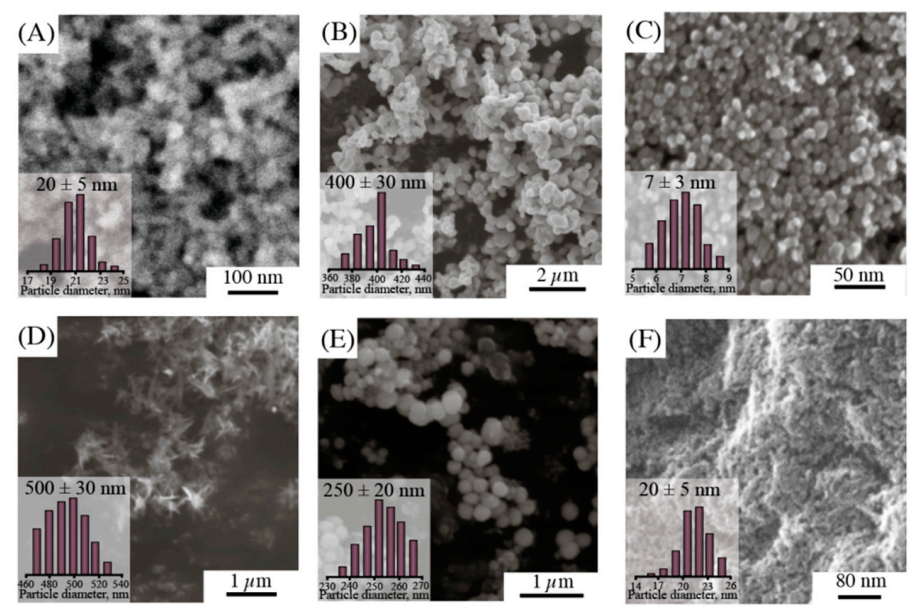

Figure 2. SEM images and particle size distribution by SEM of NPs: (A) $\mathrm{TiO}_{2}$, (B) $\mathrm{Ag}_{2} \mathrm{O},(\mathbf{C}) \mathrm{Fe}_{3} \mathrm{O}_{4}$, (D) $\mathrm{CuO}$, (E) $\mathrm{ZnO},($ F) $\mathrm{AlOOH}$.
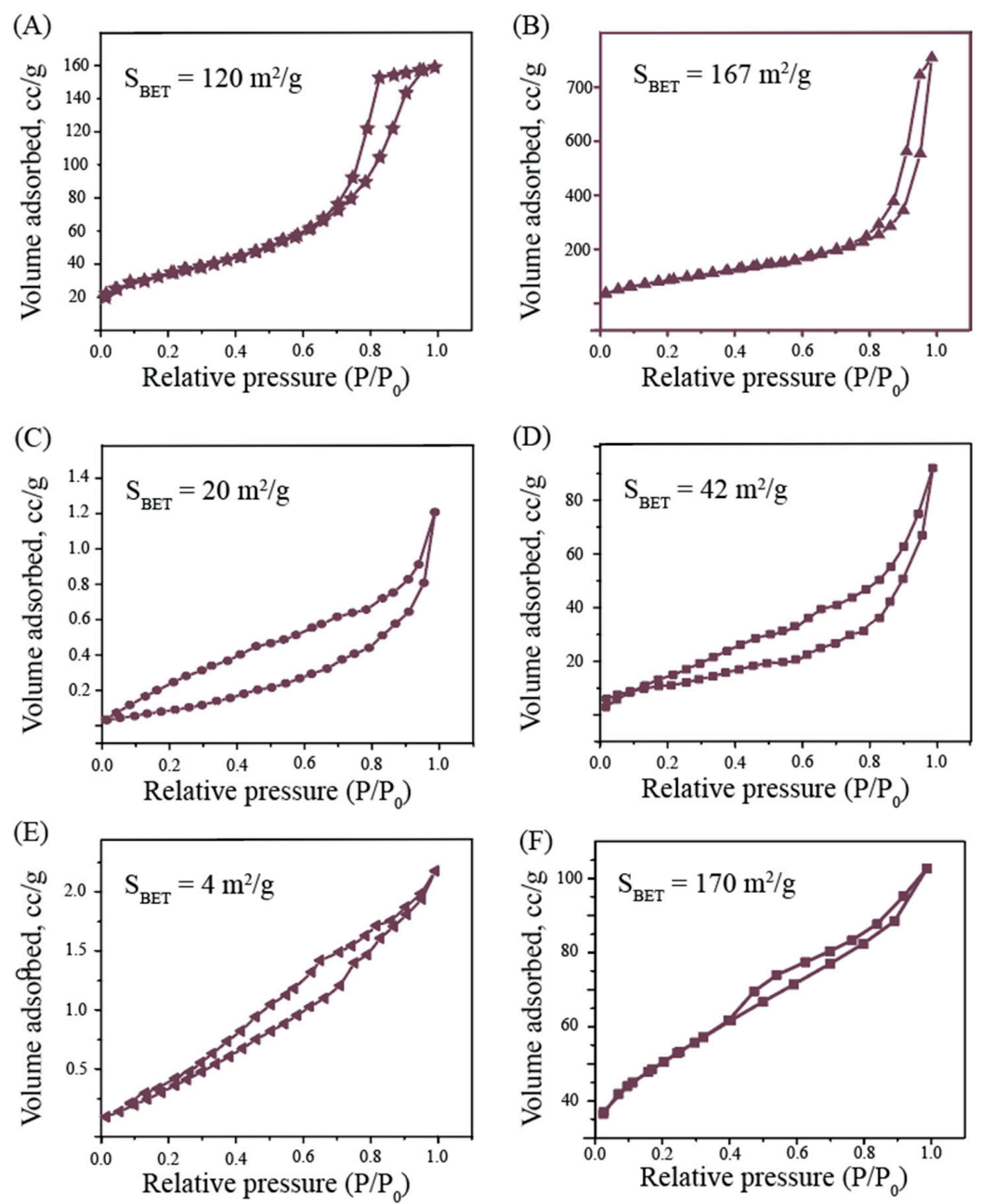

Figure 3. Characterization of samples by low-temperature physisorption. Shown are nitrogen adsorption-desorption isotherms of NPs: (A) $\mathrm{Fe}_{3} \mathrm{O}_{4}$, (B) $\mathrm{TiO}_{2}$, (C) $\mathrm{ZnO},(\mathbf{D}) \mathrm{CuO},(\mathbf{E}) \mathrm{Ag}_{2} \mathrm{O},(\mathbf{F}) \mathrm{AlOOH}$. The surface area for all samples was calculated by the BET method. 


\subsection{Cytotoxicity of NPs}

$\mathrm{Fe}_{3} \mathrm{O}_{4}, \mathrm{TiO}_{2}$, and $\mathrm{AlOOH}$ NPs evoked no cytotoxic effects on human monocytic cells (THP-1 line) at the range of concentrations of $0.234-30 \mu \mathrm{g} / \mathrm{mL}$ for at least $72 \mathrm{~h}$ of continuous exposure. The cell survival rate did not fall below $80 \%$. No morphological signs of death were detectable, indicating that even the maximum concentrations used in this experiment were tolerable. $\mathrm{Ag}_{2} \mathrm{O}$ NPs were cytotoxic at $30 \mu \mathrm{g} / \mathrm{mL}$, whereas at $0.234-15 \mu \mathrm{g} / \mathrm{mL}$, cell viability was $\geq 80 \%$. CuO and $\mathrm{ZnO}$ were toxic at $\geq 15 \mu \mathrm{g} / \mathrm{mL}$ (Figure 4). In general, the results of the cytotoxicity analysis coincide with the previously published results $[61,62]$. Using the results of this analysis, we have calculated the optimal NP concentrations to analyze their effects on TLR-4 and -6 expression.

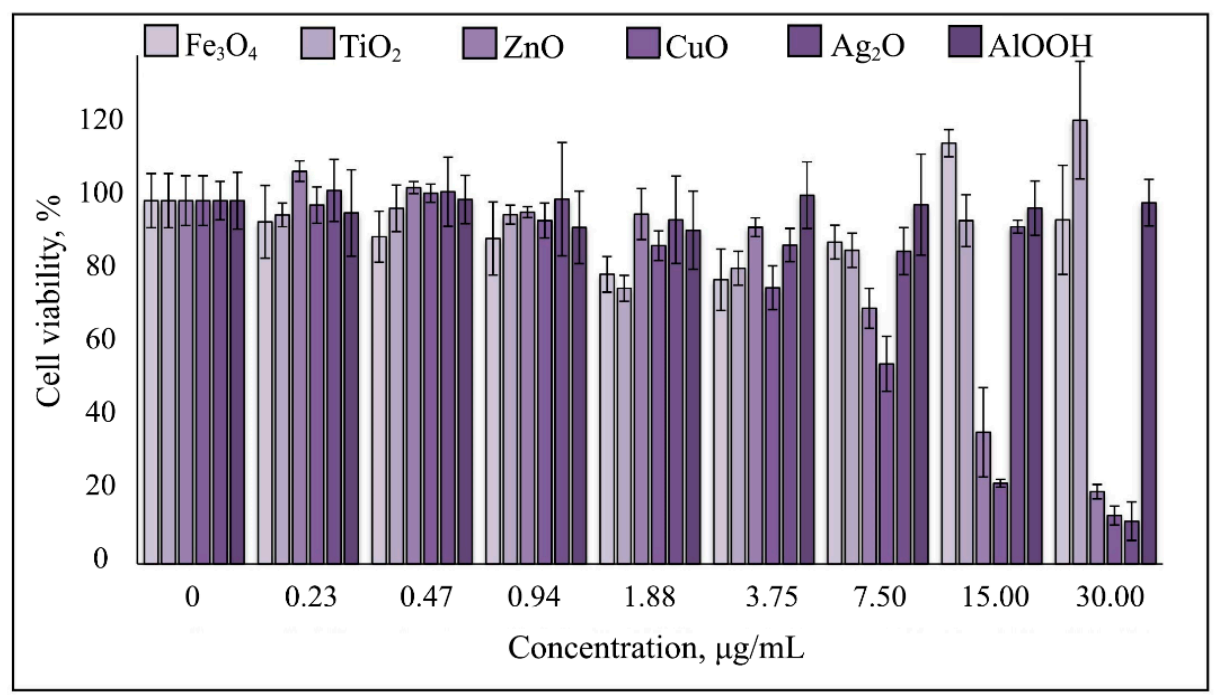

Figure 4. Cytotoxicity of $\mathrm{Fe}_{3} \mathrm{O}_{4}, \mathrm{AlOOH}, \mathrm{TiO}_{2}, \mathrm{Ag}_{2} \mathrm{O}, \mathrm{CuO}$, and $\mathrm{ZnO}$ NPs after $72 \mathrm{~h}$ of exposure of the THP-1 monocyte cell line. Shown are the mean of three independent experiments (three replicates in each) \pm standard deviation.

\subsection{NPs Enhance TLR-4 and TLR-6 mRNA Levels in THP-1 Cells}

In this study, we aimed to demonstrate the immune system response caused by the exposure to NPs on the model of activation of TLRs in THP-1 monocytes. This study is relevant because the NPs used in the investigation have a high therapeutic potential and can be used to create new approaches to the treatment of diseases, such as bacterial and fungal infections, through the additional stimulation of the immune system [36-38]. TLRs are present in most cell types and are part of the signaling pathways that respond to various compounds; in particular, bacterial cell wall components such as lipopolysaccharide $[39,40]$. They cause the activation of cellular mechanisms that lead to increased activity of $\mathrm{T}$ and $\mathrm{B}$ cells, as well as macrophages. This provides an immune response [62].

To estimate the influence of NPs on TLR- 4 and -6 mRNAs in THP-1 monocytes, we used the concentrations at which cell viability was at least $80 \%$ as determined in MTT tests. We accepted that the corresponding equipotent values for these viability levels were as follows: $30 \mu \mathrm{g} / \mathrm{mL}$ for $\mathrm{Fe}_{3} \mathrm{O}_{4}$ and $\mathrm{AlOOH}, 25 \mu \mathrm{g} / \mathrm{mL}$ for $\mathrm{TiO}_{2}, 15 \mu \mathrm{g} / \mathrm{mL}$ for $\mathrm{Ag}_{2} \mathrm{O}, 1 \mu \mathrm{g} / \mathrm{mL} \mathrm{ZnO}$, and $0.5 \mu \mathrm{g} / \mathrm{mL}$ for CuO. Here, we incubated cells with these NPs or with $1 \mu \mathrm{g} / \mathrm{mL}$ LPS as a positive inductor of TLR response for $24 \mathrm{~h}$.

All the studied NPs increased the TLRs' expression to different degrees (Figure 5), however, the maximum induction was comparable with one after the LPS exposure. The maximum induction of TLR-4 was observed under the AlOOH NPs' influence, which increased the expression 1.5-fold. Of note, the level of TLR-4 following $\mathrm{AlOOH}$ was comparable with that of $\mathrm{LPS}$. $\mathrm{CuO}, \mathrm{ZnO}$, and $\mathrm{TiO}_{2}$ NPs increased the expression less significantly: 1.2, 1.2, and 1.1-fold, respectively. $\mathrm{Ag}_{2} \mathrm{O}$ and $\mathrm{Fe}_{3} \mathrm{O}_{4}$ did not affect the TLR-4 expression. TLR-6 was also the most induced by AlOOH NPs-1.6-fold. Among the other particles, $\mathrm{Ag}_{2} \mathrm{O}, \mathrm{TiO}_{2}$, and $\mathrm{CuO}$ were more potent: fold induction values were 1.5, 
1.5 , and 1.5, respectively. The least comparative effects were produced by $\mathrm{ZnO}$ and $\mathrm{Fe}_{3} \mathrm{O}_{4} \mathrm{NPs}$, which increased the expression 1.4-fold. Thus, the most potent TLR inductor is $\mathrm{AlOOH} \mathrm{NPs.} \mathrm{CuO}$ and $\mathrm{TiO}_{2}$ NPs also stimulated the expression of both TLRs, but to a lesser extent. Silver did not affect the TLR-4 but instead strongly induced TLR-6. The most unreactive NPs were $\mathrm{Fe}_{3} \mathrm{O}_{4}$.
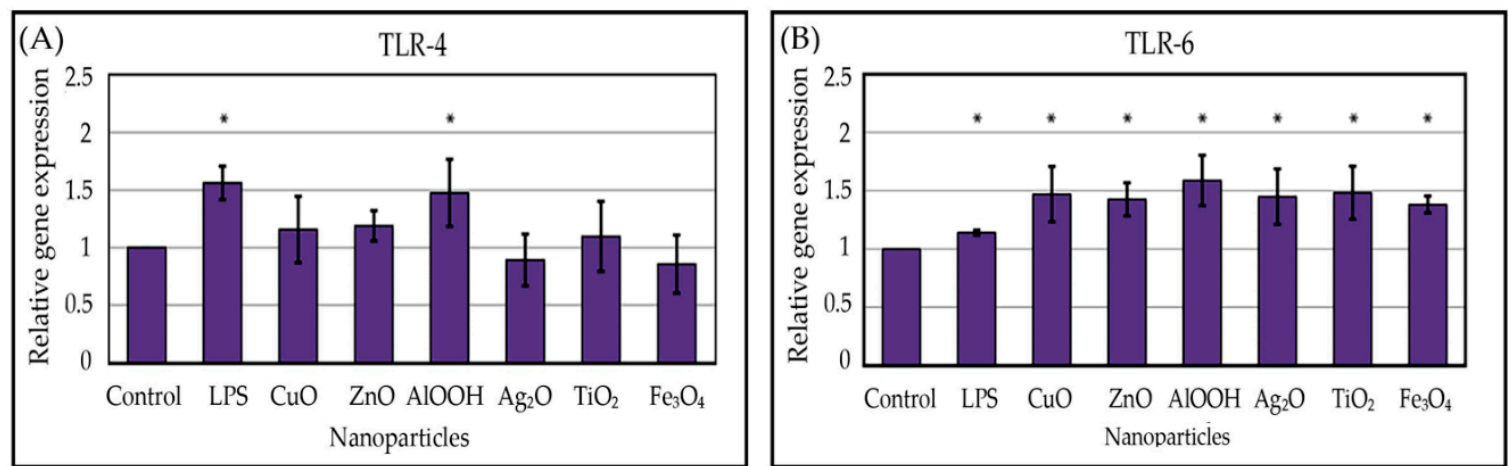

Figure 5. Relative expression of toll-like receptor 4 (TLR-4) (A) and TLR-6 (B) genes in THP-1 cells after $24 \mathrm{~h}$ exposure to NPs or lipopolysaccharide (LPS). Shown are the mean of three independent experiments (three replicates in each) \pm standard deviation. See Materials and Methods for details. ${ }^{*} p$ $<0.05$.

For some NPs we studied, immune response stimulation, including TLR-mediated stimulation, has been shown earlier [41-49]. In some cases, the TLR expression data we obtained were slightly lower than the previously published data. In particular, it has been shown that magnetite NPs specifically induced macrophage autophagy through activation of TLR-4 [16]. In our case, the $\mathrm{Fe}_{3} \mathrm{O}_{4} \mathrm{NPs}$ did not affect the TLR-4. In addition, it has been shown that among the TLRs, TLR- 6 was the most potent activator of inflammatory reactions induced by ZnO NPs [54]. In our study, they did activate the TLR-6 more strongly than the TLR-4, but in comparison with other NPs, their effect on the TLR- 6 was one of the lowest. Such a discrepancy may be due to the peculiarities of NP synthesis, which causes their increased toxicity and immunogenicity, as well as the peculiarities of experiments on biological models. In this regard, it is especially important to conduct a systematic study of a set of NPs characterized and synthesized simultaneously in the same or similar conditions.

\section{Conclusions}

In this study, we analyzed the influence of metal oxide NPs on innate immunity by testing TLR-4 and -6 mRNAs in response to these nanomaterials in the human monocyte cell line. We detected no cytotoxicity for $72 \mathrm{~h}$ at $30 \mu \mathrm{g} / \mathrm{mL}$ for $\mathrm{Fe}_{3} \mathrm{O}_{4}$ and $\mathrm{AlOOH}, 25 \mu \mathrm{g} / \mathrm{mL}$ for $\mathrm{TiO}_{2}, 15 \mu \mathrm{g} / \mathrm{mL}$ for $\mathrm{Ag}_{2} \mathrm{O}$, $0.5 \mu \mathrm{g} / \mathrm{mL}$ for $\mathrm{CuO}$, and $1 \mu \mathrm{g} / \mathrm{mL}$ for $\mathrm{ZnO}$ (the range of investigated concentrations was chosen according to the maximum NP concentration, forming stable sol in aqueous solution). All studied NPs activated TLR- 6 expression, whereas AlOOH enhanced both TLR-4 and -6 . Thus, the use of these NPs in vivo may have a dual effect, due to stimulation of the innate immune system. The effect may be beneficial due to the increased expression of anti-inflammatory cytokines. It is of particular importance for drug development against bacterial or fungal infections, where additional stimulation of the immune system can accelerate the antimicrobial response and tissue repair. However, these effects should be kept in mind when using these materials for anticancer drug development, since the attraction of immune cells to the tumor may be clinically unfavorable. At any rate, it should be noted that the maximum induction of expression was not very strong. The described results demonstrate only the potential effect of NPs on innate immunity, and emphasize the need for further research in this direction. 
Author Contributions: V.A.V., S.A.T., and E.I.A. performed the experiments. V.A.V., E.I.A., A.F.F., A.S.M. and E.I.K. drafted the manuscript. E.I.K., A.F.F., A.A.S., and V.V.V. designed the study. All authors have read and agreed to the published version of the manuscript.

Funding: This work was supported by the Russian Science Foundation (grant number 19-74-00125).

Acknowledgments: The authors are grateful to D. P. Danilovich for comprehensive support and to the engineering center of Saint Petersburg Technological Institute for research assistance with XRD measurements. The authors thank Grigorii Kiselev for the synthesis of alumina nanoparticles.

Conflicts of Interest: The authors declare no conflict of interest.

\section{References}

1. Farrell, E.; Wielopolski, P.; Pavljasevic, P.; Kops, N.; Weinans, H.; Bernsen, M.; Van Osch, G. Cell labelling with superparamagnetic iron oxide has no effect on chondrocyte behavior. Osteoarthr. Cartil. 2009, 17, 961-967. [CrossRef] [PubMed]

2. Yoshida, Y.; Fukui, S.; Fujimoto, S.; Mishima, F.; Takeda, S.; Izumi, Y.; Ohtani, S.; Fujitani, Y.; Nishijima, S. Ex vivo investigation of magnetically targeted drug delivery system. J. Magn. Magn. Mater. 2007, 310, 2880-2882. [CrossRef]

3. Bucak, S.; Jones, D.; Laibinis, P.; Hatton, T. Protein separations using colloidal magnetic nanoparticles. Biotechnol. Prog. 2003, 19, 477-484. [CrossRef] [PubMed]

4. Jun, B.-H.; Noh, M.S.; Kim, G.; Kang, H.; Kim, J.-H.; Chung, W.-J.; Kim, M.-S.; Kim, Y.-K.; Cho, M.-H.; Jeong, D.H.; et al. Protein separation and identification using magnetic beads encoded with surface-enhanced Raman spectroscopy. Anal. Biochem. 2009, 391, 24-30. [CrossRef] [PubMed]

5. Corti, M.; Lascialfari, A.; Marinone, M.; Masotti, A.; Micotti, E.; Orsini, F.; Ortaggi, G.; Poletti, G.; Innocenti, C.; Sangregorio, C. Magnetic and relaxometric properties of polyethylenimine-coated superparamagnetic MRI contrast agents. J. Magn. Magn. Mater. 2008, 320, e316-e319. [CrossRef]

6. Jain, T.K.; Richey, J.; Strand, M.; Leslie-Pelecky, D.L.; Flask, C.A.; Labhasetwar, V. Magnetic nanoparticles with dual functional properties: Drug delivery and magnetic resonance imaging. Biomaterials 2008, 29, 4012-4021. [CrossRef]

7. Hergt, R.; Dutz, S. Magnetic particle hyperthermia-biophysical limitations of a visionary tumour therapy. J. Magn. Magn. Mater. 2007, 311, 187-192. [CrossRef]

8. Jordan, A.; Scholz, R.; Wust, P.; Fähling, H.; Felix, R. Magnetic fluid hyperthermia (MFH): Cancer treatment with AC magnetic field induced excitation of biocompatible superparamagnetic nanoparticles. J. Magn. Magn. Mater. 1999, 201, 413-419. [CrossRef]

9. Maity, D.; Agrawal, D. Synthesis of iron oxide nanoparticles under oxidizing environment and their stabilization in aqueous and non-aqueous media. J. Magn. Magn. Mater. 2007, 308, 46-55. [CrossRef]

10. Medina, C.; Santos-Martinez, M.J.; Radomski, A.; Corrigan, O.I.; Radomski, M.W. Nanoparticles: Pharmacological and toxicological significance. Br. J. Pharmacol. 2007, 150, 552-558. [CrossRef]

11. Jain, J.; Arora, S.; Rajwade, J.M.; Omray, P.; Khandelwal, S.; Paknikar, K.M. Silver nanoparticles in therapeutics: Development of an antimicrobial gel formulation for topical use. Mol. Pharm. 2009, 6, 1388-1401. [CrossRef] [PubMed]

12. Rasmussen, J.W.; Martinez, E.; Louka, P.; Wingett, D.G. Zinc oxide nanoparticles for selective destruction of tumor cells and potential for drug delivery applications. Expert Opin. Drug Deliv. 2010, 7, 1063-1077. [CrossRef] [PubMed]

13. Vinardell, M.P.; Mitjans, M. Antitumor activities of metal oxide nanoparticles. Nanomaterials 2015, 5, 1004-1021. [CrossRef] [PubMed]

14. Bashir, M.R.; Bhatti, L.; Marin, D.; Nelson, R.C. Emerging applications for ferumoxytol as a contrast agent in MRI. J. Magn. Reson. Imaging 2015, 41, 884-898. [CrossRef] [PubMed]

15. Bulte, J.W.M.; Kraitchman, D.L. Iron oxide MR contrast agents for molecular and cellular imaging. NMR Biomed. 2004, 17, 484-499. [CrossRef]

16. Jin, R.; Liu, L.; Zhu, W.; Li, D.; Yang, L.; Duan, J.; Cai, Z.; Nie, Y.; Zhang, Y.; Gong, Q.; et al. Iron oxide nanoparticles promote macrophage autophagy and inflammatory response through activation of toll-like Receptor-4 signaling. Biomaterials 2019, 203, 23-30. [CrossRef] 
17. Chen, X.; Mao, S.S. Titanium dioxide nanomaterials: Synthesis, properties, modifications and applications. Chem. Rev. 2007, 107, 2891-2959. [CrossRef]

18. RajeshKumar, S.; Lakshmi, T.; Naik, P. Recent advances and biomedical applications of zinc oxide nanoparticles. In Green Synthesis, Characterization and Applications of Nanoparticles; Elsevier: Amsterdam, The Netherlands, 2019; pp. 445-457. [CrossRef]

19. Alizadeh, T.; Mirzagholipur, S. A Nafion-free non-enzymatic amperometric glucose sensor based on copper oxide nanoparticles-graphene nanocomposite. Sens. Actuators B Chem. 2014, 198, 438-447. [CrossRef]

20. Nguyen, T.-T.; Huy, B.T.; Hwang, S.-Y.; Vuong, N.M.; Pham, Q.-T.; Nghia, N.N.; Kirtland, A.; Lee, Y.-I. Preparing cuprous oxide nanomaterials by electrochemical method for non-enzymatic glucose biosensor. Nanotechnology 2018, 29, 205501. [CrossRef]

21. Di Tocco, A.; Robledo, S.; Osuna, Y.; Sandoval-Cortez, J.; Granero, A.; Vettorazzi, N.; Martínez, J.; Segura, E.; Iliná, A.; Zon, M.; et al. Development of an electrochemical biosensor for the determination of triglycerides in serum samples based on a lipase/magnetite-chitosan/copper oxide nanoparticles/multiwalled carbon nanotubes/pectin composite. Talanta 2018, 190, 30-37. [CrossRef]

22. Abiraman, T.; Ramanathan, E.; Kavitha, G.; Rengasamy, R.; Balasubramanian, S. Synthesis of chitosan capped copper oxide nanoleaves using high intensity $(30 \mathrm{kHz})$ ultrasound sonication and their application in antifouling coatings. Ultrason. Sonochem. 2017, 34, 781-791. [CrossRef] [PubMed]

23. Zhao, C.; Lv, J.; Xu, X.; Zhang, G.; Yang, Y.; Yang, F. Highly antifouling and antibacterial performance of poly (vinylidene fluoride) ultrafiltration membranes blending with copper oxide and graphene oxide nanofillers for effective wastewater treatment. J. Colloid Interface Sci. 2017, 505, 341-351. [CrossRef] [PubMed]

24. Sivaraj, R.; Rahman, P.K.; Rajiv, P.; Salam, H.A.; Venckatesh, R. Biogenic copper oxide nanoparticles synthesis using Tabernaemontana divaricate leaf extract and its antibacterial activity against urinary tract pathogen. Spectrochim. Acta Part A Mol. Biomol. Spectrosc. 2014, 133, 178-181. [CrossRef] [PubMed]

25. Dizaj, S.M.; Lotfipour, F.; Barzegar-Jalali, M.; Zarrintan, M.H.; Adibkia, K. Antimicrobial activity of the metals and metal oxide nanoparticles. Mater. Sci. Eng. C 2014, 44, 278-284. [CrossRef] [PubMed]

26. Dandapani, V.; Bhuvaneshwari, V.; Bharathi, D.; Sheetal, B.P. Antibacterial and photocatalytic activity of copper oxide nanoparticles synthesized using Solanum lycopersicum leaf extract. Mater. Res. Express 2018, 5, 085403. [CrossRef]

27. Wang, Y.; Yang, F.; Zhang, H.-X.; Zi, X.-Y.; Pan, X.-H.; Chen, F.; Luo, W.-D.; Li, J.-X.; Zhu, H.-Y.; Hu, Y.-P. Cuprous oxide nanoparticles inhibit the growth and metastasis of melanoma by targeting mitochondria. Cell Death Dis. 2013, 4, e783. [CrossRef]

28. Yang, Q.; Wang, Y.; Yang, Q.; Gao, Y.; Duan, X.; Fu, Q.; Chu, C.; Pan, X.; Cui, X.; Sun, Y. Cuprous oxide nanoparticles trigger ER stress-induced apoptosis by regulating copper trafficking and overcoming resistance to sunitinib therapy in renal cancer. Biomaterials 2017, 146, 72-85. [CrossRef]

29. Wu, N.; Zhang, C.; Wang, C.; Song, L.; Yao, W.; Gedanken, A.; Lin, X.; Shi, D. Zinc-doped copper oxide nanocomposites reverse temozolomide resistance in glioblastoma by inhibiting AKT and ERK1/2. Nanomedicine 2018, 13, 1303-1318. [CrossRef]

30. He, P.; Zou, Y.; Hu, Z. Advances in aluminum hydroxide-based adjuvant research and its mechanism. Hum. Vaccines Immunother. 2015, 11, 477-488. [CrossRef]

31. Lindblad, E.B. Aluminium compounds for use in vaccines. Immunol. Cell Biol. 2004, 82, 497-505. [CrossRef]

32. Wang, Y.H.; Gu, H.Y. Hemoglobin co-immobilized with silver-silver oxide nanoparticles on a bare silver electrode for hydrogen peroxide electroanalysis. Microchim. Acta 2009, 164, 41-47. [CrossRef]

33. Otari, S.V.; Patel SK, S.; Kalia, V.C.; Kim, I.W.; Lee, J.K. Antimicrobial Activity of Biosynthesized Silver Nanoparticles Decorated Silica Nanoparticles. Indian J. Microbiol. 2014, 59, 379-382. [CrossRef] [PubMed]

34. Manikandan, V.; Velmurugan, P.; Park, J.-H.; Chang, W.-S.; Park, Y.-J.; Jayanthi, P.; Cho, M.; Oh, B.-T. Green synthesis of silver oxide nanoparticles and its antibacterial activity against dental pathogens. 3 Biotech 2017, 7, 6393. [CrossRef] [PubMed]

35. Iqbal, S.; Fakhar-E-Alam, M.; Akbar, F.; Shafiq, M.; Atif, M.; Amin, N.; Ismail, M.; Hanif, A.; Farooq, W.A. Application of silver oxide nanoparticles for the treatment of cancer. J. Mol. Struct. 2019, 1189, 203-209. [CrossRef]

36. Ilinskaya, A.N.; Dobrovolskaia, M.A. Immunosuppressive and anti-inflammatory properties of engineered nanomaterials. Br. J. Pharmacol. 2014, 171, 3988-4000. [CrossRef] 
37. Liu, X.; Xue, Y.; Ding, T.; Sun, J. Enhancement of pro-inflammatory and procoagulant responses to silica particles by monocyte-endothelial cell interactions. Part. Fibre Toxicol. 2012, 9, 36. [CrossRef]

38. Sahu, D.; Kannan, G.M.; Vijayaraghavan, R. Size-dependent effect of zinc oxide on toxicity and inflammatory potential of human monocytes. J. Toxicol. Environ. Health Part A 2014, 77, 177-191. [CrossRef] [PubMed]

39. Trinchieri, G.; Sher, A. Cooperation of Toll-like receptor signals in innate immune defence. Nat. Rev. Immunol. 2007, 7, 179-190. [CrossRef] [PubMed]

40. Kawai, T.; Akira, S. The role of pattern-recognition receptors in innate immunity: Update on toll-like receptors. Nat. Immunol. 2010, 11, 373-384. [CrossRef]

41. Smith, U.M.; Simon, J.K.; Baker, J.R., Jr. Applications of nanotechnology for immunology. Nat. Rev. Immunol. 2013, 13, 592-605. [CrossRef]

42. Lucarelli, M.; Gatti, A.M.; Savarino, G.; Quattroni, P.; Martinelli, L.; Monari, E.; Boraschi, D. Innate defence functions of macrophages can be biased by nano-sized ceramic and metallic particles. Eur. Cytokine Netw. 2004, 15, 339-346. [PubMed]

43. Cui, Y.; Liu, H.; Zhou, M.; Duan, Y.; Li, N.; Gong, X.; Hu, R.; Hong, M.; Hong, F. Signaling pathway of inflammatory responses in the mouse liver caused by $\mathrm{TiO}_{2}$ nanoparticles. J. Biomed. Mater. Res. Part A 2011, 96, 221-229. [CrossRef] [PubMed]

44. Elsabahy, M.; Wooley, K.L. Cytokines as biomarkers of nanoparticle immunotoxicity. Chem. Soc. Rev. 2013, 42, 5552-5576. [CrossRef] [PubMed]

45. Schanen, B.C.; Karakoti, A.S.; Seal, S.; Iii, N.R.D.; Warren, W.L.; Self, W.T.; Drake, N.R. Exposure to titanium dioxide nanomaterials provokes inflammation of an in vitro human immune construct. ACS Nano 2009, 3, 2523-2532. [CrossRef]

46. Ghoneum, M.; Ghoneum, A.; Gimzewski, J. Nanodiamond and nanoplatinum liquid, DPV576, activates human monocyte-derived dendritic cells in vitro. Anticancer Res. 2010, 30, 4075-4079.

47. Hanley, C.; Thurber, A.; Hanna, C.; Punnoose, A.; Zhang, J.; Wingett, D.G. The influences of cell Type and $\mathrm{ZnO}$ nanoparticle size on immune cell cytotoxicity and cytokine induction. Nanoscale Res. Lett. 2009, 4, 1409-1420. [CrossRef]

48. Yazdi, A.S.; Guarda, G.; Riteau, N.; Drexler, S.K.; Tardivel, A.; Couillin, I.; Tschopp, J. Nanoparticles activate the NLR pyrin domain containing 3 (Nlrp3) inflammasome and cause pulmonary inflammation through release of IL-1 $\alpha$ and IL-1ß. Proc. Natl. Acad. Sci. USA 2010, 107, 19449-19454. [CrossRef]

49. Hornung, V.; Bauernfeind, F.; Halle, A.; Samstad, E.O.; Kono, H.; Rock, K.L.; Fitzgerald, K.A.; Latz, E. Silica crystals and aluminum salts activate the NALP3 inflammasome through phagosomal destabilization. Nat. Immunol. 2008, 9, 847-856. [CrossRef]

50. Anderson, J.M.; Rodriguez, A.; Chang, D.T. Foreign body reaction to biomaterials. In Seminars in Immunology; Academic Press: Cambridge, MA, USA, 2008; Volume 20, pp. 86-100. [CrossRef]

51. Getts, D.R.; Shea, L.D.; Miller, S.D.; King, N.J. Harnessing nanoparticles for immune modulation. Trends Immunol. 2015, 36, 419-427. [CrossRef]

52. Wolf-Grosse, S.; Mollnes, T.E.; Ali, S.; Stenvik, J.; Nilsen, A.M. Iron oxide nanoparticles enhance Toll-like receptor-induced cytokines in a particle size-and actin-dependent manner in human blood. Nanomedicine 2018, 13. [CrossRef]

53. Castillo, P.M.; Herrera, J.L.; Fernández-Montesinos, R.; Caro, C.; Zaderenko, A.P.; Mejías, J.A.; Pozo, D.; Salazar, C.C.; Perez, P.D.D.P. Tiopronin monolayer-protected silver nanoparticles modulate IL-6 secretion mediated by Toll-like receptor ligands. Nanomedicine 2008, 3, 627-635. [CrossRef] [PubMed]

54. Roy, R.; Singh, S.K.; Das, M.; Tripathi, A.; Dwivedi, P.D. Toll-like receptor 6 mediated inflammatory and functional responses of zinc oxide nanoparticles primed macrophages. Immunology 2014, 142, 453-464. [CrossRef] [PubMed]

55. Phiwdang, K.; Suphankij, S.; Mekprasart, W.; Pecharapa, W. Synthesis of CuO nanoparticles by precipitation method using different precursors. Energy Procedia 2013, 34, 740-745. [CrossRef]

56. Martakov, I.S.; Krivoshapkin, P.V.; Torlopov, M.A.; Krivoshapkina, E.F. Application of Chemically Modified Celluloses as Templates for Obtaining of Alumina Materials. Fibers Polym. 2015, 16, 975-981. [CrossRef]

57. Dudkin, B.N.; Krivoshapkin, P.V.; Luksha, V.G. Synthesis of aluminum oxide nanoparticles in an aqueous ammonium-formaldehyde solution. Colloid J. 2006, 68, 40-44. [CrossRef] 
58. Mikhaylov, V.; Maslennikova, T.; Krivoshapkina, E.; Tropnikov, E.; Krivoshapkin, P. Express Al/Fe oxide-oxyhydroxide sorbent systems for Cr(VI) removal from aqueous solutions. Chem. Eng. J. 2018, 350, 344-355. [CrossRef]

59. Schmittgen, T.D.; Livak, K.J. Analyzing real-time PCR data by the comparative C T method. Nat. Protoc. 2008, 3, 1101-1108. [CrossRef]

60. Zhou, W.; Liu, H.; Wang, J.; Liu, D.; Du, G.; Cui, J. $\mathrm{Ag}_{2} \mathrm{O} / \mathrm{TiO}_{2}$ nanobelts heterostructure with enhanced ultraviolet and visible photocatalytic activity. CS Appl. Mater. Interfaces 2010, 2, 2385-2392. [CrossRef]

61. Fakhardo, A.F.; Anastasova, E.I.; Gabdullina, S.R.; Solovyeva, A.S.; Saparova, V.B.; Chrishtop, V.V.; Koshevaya, E.D.; Krivoshapkina, E.F.; Krivoshapkin, P.V.; Kiselev, G.O.; et al. Toxicity Patterns of Clinically Relevant Metal Oxide Nanoparticles. ACS Appl. Biol. Mater. 2019, 2, 4427-4435. [CrossRef]

62. Reynolds, J.M.; Martinez, G.J.; Chung, Y.; Dong, C. Toll-like receptor 4 signaling in T cells promotes autoimmune inflammation. Proc. Natl. Acad. Sci. USA 2012, 109, 13064-13069. [CrossRef]

(C) 2020 by the authors. Licensee MDPI, Basel, Switzerland. This article is an open access article distributed under the terms and conditions of the Creative Commons Attribution (CC BY) license (http://creativecommons.org/licenses/by/4.0/). 